\title{
Implementation of Religious Activities in Increasing the Spiritual Intelligence of Students
}

\author{
Deli Musdalifa ${ }^{*}$,Fatimah Saguni ${ }^{2}$, and Gusnarib Gusnarib ${ }^{3}$ \\ ${ }^{1}$ Islamic Education Department, Postgraduate, Institut Agama Islam Negeri Palu \\ 2 Islamic Education Department, Postgraduate, Institut Agama Islam Negeri Palu \\ ${ }^{3}$ Islamic Education Department, Postgraduate, Institut Agama Islam Negeri Palu
}

\begin{abstract}
The aim of this paper is to discusses the practice of cousin marriage in the community of Kalola Village, Pasangkayu Regency, West Sulawesi. This study uses qualitative methods and data was gathered through observation, in-depth interviews, and written material. Data analysis was analyzed using grounded theory approach. The results show that the religious activities in MAN insan Cendekia Palu City were congregational prayer activities, qiroatul quran, tahfiz Alquran, Qiro'ah qabla naum, Ratibul haddal / barzanji, polar Qiraatul / book study, three-language cult. The religious activities are carried out outside school hours, from $05.00-05.30$ and continued at 18.30-19.15 and then continued again at 21.45-22.00, the activities are carried out at the mosque for male students and in the dormitory for girls, for brazanji and evening prayers and Isha all students carry out in the mushollah. Togetherness activities have six coaches, namely 3 male dormitory coaches and 3 female coaches, the friendship activity supervisor is a competent coach with activities carried out by the implementation process itself carried out by providing training, coaching and habituation so that the expected goals can be achieved.
\end{abstract}

\section{ARTICLE \\ INFORMATION}

\section{Keywords:}

Religious activities, spritual intelligence, students 


\section{Introduction}

Education plays a role in shaping the good and bad attitude of a person, education provides a very large contribution in life, there is something interesting about the current education system in Indonesia, namely that education in Indonesia has developed.

The educational process is expected to be able to help humans meet the needs of their souls for the belief and faith that humans are God's creatures. This belief leads to self-recognition that human power is a gift from God for His power. From the point of view of creating awareness of meaning and purpose of life, it must be placed in the divine spirit. This belief gives birth to an inner attitude that the happiness of life can be felt in this world in the form of peace and tranquility of the soul that comes from Allah SWT. Peace of mind can be obtained by a deep feeling of love for Allah SWT which grows from the feeling of always remembering God. This need for taste is called spiritual need.

With the development of technology, it really plays a role in the quality of life. Therefore, without being followed by the maturity of intelligence, social emotional, spiritual and moral as personal guidelines, all information will be easily accepted by students as essential truth.

A person who is studying needs to maintain a sense of faith so that it becomes stronger because faith is a guidance, a guide given to us, next is how to take piety by understanding Islam which involves faith, sharia and morals in earnest. A person who studies seriously to study Islamic activities will certainly spend more on studying at a boarding school or a school that implements a boarding school system.

In general, schools have the same concept where students go to school or madrasah. With the development of an increasingly modern era where most parents are busy with their respective jobs so that their children cannot be controlled properly, besides that it is necessary to cultivate religious knowledge because general knowledge is not enough, it is necessary to have a boarding school so that students can be well maintained and can strengthen their religious knowledge, dormitories are a solution in dealing with. ${ }^{1}$

A boarding school is an institution in the form of a school or madrasa but has a special feature in which there is a dormitory which is used as a reference in improving the quality of the school or madrasah. In dormitory activities there is a religious learning activity.

Parents who really want the continuity of the education of their sons and daughters to become successful people both in general knowledge, skills and religious knowledge. With this, parents choose madrasah that really accommodate their children for their future. MAN Insan Cendekia Kota Palu

\footnotetext{
${ }^{1}$ Evita, E., Syahid, A., \& Nurdin, N. (2019). Understanding Students' Learning Outcomes Differences Through the Application of the Market Place Activity Type of Cooperative Learning Model and the Application of Conventional Learning Models International Journal of Contemporary Islamic Education, 1(1), 6785.
} 
is a madrasa that applies education with a boarding school system.

MAN Insan Cendekia Palu City was formed in 2016 where it held general and religious education from morning to evening and continued with religious activities at night, which were held in prayer rooms and in girls' dormitories at night and dawn. Dormitory is a place to live that separates the physical interactions between students and parents. So that they are required to be more independent in realizing their dreams and self-development as well as how students are required to socialize with a more diverse environment as it is known that students at MAN Insan Cendekia Palu City are not only from Palu City but also from outside Palu City.

Even from other provinces, so that students are expected to be able to socialize well in their own environment rather than among their own families, especially in terms of exemplary morals, it is hoped that after this hostel will be able to be role models specifically for their own families at home, dormitories also have specific rules or regulations. which is implemented like pesantren in general and in this case to gain moral knowledge, to achieve role model attitude in a dormitory, it requires a dormitory assistant and supervisor as a substitute for parents.

In the dormitory MAN Insan Cendekia Kota Palu it has various programs that are used as references in increasing the moral and intelligence, emotional and spiritual, activities are carried out in the dormitory and in the prayer room starting at night until dawn, these activities include; congregational prayer activities, Qiroatul quran activities, Tahfizul Alquran activities, Qiro'ah qabla naum activities, polar Qiraatul activities, barazanji activities, trilingual qultum activities.

The purpose of the boarding school program at MAN Insan Cendekia Palu City is the madrasah program for religious strengthening. It is hoped that students become students who master science technology and also religiousity, so various forms of activities are made that can realize the mission of madrasa, one of which is through religious activities.

MAN Insan Cendekia Palu City is the only madrasa that implements education with a boarding school system, and what makes it different is the existence of the dormitory program, in MAN Insan Cendekia Palu City, the students are not only from Palu City but also outside of Central Sulawesi such as Java, Makassar and Gorontalo.

The supervisor are one of the role models for their students in the effort to form and increase spiritual intelligence at MAN Insan Cendekia Palu City starting from the family and madrasah environment, as we know that the education and guidance given to students when they are children will have an influence strong in the soul and environment of society. With the implementation of the religious program, namely the activities described above, it is possible to influence the spiritual intelligence of students. 


\section{Literature review}

\subsection{Definition of Dormitory Activities}

According to the Indonesian dictionary, activity is an effort, work or strength and dexterity and excitement. Activities can be defined as encouragement or organized behavior and goals or things done by humans. ${ }^{2}$, Activities part of a program carried out by one or more work units as part of achieving measurable targets in a program and consists of a set of actions.

Similarity or commonly known as boarding school are:

Pondok or it can be called a santri (student) dormitory, the term pondok at the beginning of its development comes from the word funduq which means a simple bedroom which is deliberately provided by kyai (dormitory supervisors) for those who live far away and hope to stay because they want to study religion in the environment of boarding school. In one room or bedroom, usually contains more than two or three people. ${ }^{3}$

From the definition above, it can be understood that equality activities are activities that are programmed from institutions / institutions carried out in a dormitory environment with activities that are structured so that students can increase their understanding of religion.

\subsection{Purpose of dormitory activities}

The objectives of dormitory activities or commonly known as

\footnotetext{
2Soekamto, Kamus Sosiologi (Jakarta: Rajawali Press, 2000), 9.

3Taqiyuddin, Pendidikan Islam dalam Lintas Sejarah Nasional (Cirebon: Pangger, 2011), 117.
}

religious activities to be achieved are as follows:

a. Increasing the intensity of Islamic preaching to students in order to build students as a religious young generation, as the implementation of Islam is rahmatal lil alamin.

b. Build students' awareness that religious activities will motivate good and continuous religious attitudes.

c. Build personal learners who are accustomed to carrying out prayers.

d. Creating a generation with a good spiritual level (SQ), so that it will give birth to a generation that supports high ethical, moral and religious values.

e. Improve the abilities of students with cognitive, affective and psychomotor aspects.

f. Preparing students as Muslims who are able to broadcast Islam. ${ }^{4}$

The objectives of dormitory activities or religious activities are, firstly as an educational and skills institution, secondly as a forum for activities, thirdly as a center for guidance and development, fourthly as a communication network, ukhuwah and friendship ${ }^{5}, 6$, the fifth functions and aims as a place of learning- teaching. The function and purpose of religious activities are expected to have good

\footnotetext{
4B. Suryosubroto, Proses Belajar Mengajar di Sekolah (Jakarta: Rineka Cipta, 1992), 192.

5 Rusli, R. (2018). Fikih Ekologi dan Kearifan Tradisional: Tinjauan Terhadap Konsep Ihya' al-Mawat dan Hima. Hunafa: Jurnal Studia Islamika, 5(3), 287-298.

${ }^{6}$ Rusli, R. (2020). The Role of Family in Preventing Social Conflict in Society From Islamic Perspectives. Hunafa: Jurnal Studia
} Islamika, 17(1), 108-122 
(noble) morals, increase knowledge and intelligence in order to elevate one's degree and increase good deeds, movement and struggle.

\subsection{Forms of Dormitory Activities}

Dormitory activities have many forms of activities, where these activities are to develop knowledge of Islamic Education which has implications for spiritual intelligence, forms of religious activities include:
a. Prayers in congregation
b. Qiro'atul quran
c. Tahfizul Alquran
d. Qira'ah qabla naum
e. Qiraatul kutub (book study)
f. Ratibul Haddad / barasanji
g. Qultum 3 languages (Arabic, English and Indonesian). ${ }^{7}$

The religious activities above are steps that can strengthen students' understanding of Islamic religious education materials, such as enrichment, strengthening and deepening of material such as cultural activities, barasanji, reading the Alquran, and tahfiz the Alquran.

\subsection{Spiritual Intellegence}

Etymologically, intelligence in the Indonesian Dictionary is about the perfection of the development of reason (such as intelligence, sharpness of mind). Meanwhile, spiritual intelligence is intelligence relating to the heart and care for fellow humans, other creatures, and the environment, based on the belief in

\footnotetext{
7Dokumen Wakamad Keasramaan MAN Insan Cendekia Kota Palu, 2019
}

the existence of God Almighty. ${ }^{8}$ Spiritual means spirituality or religiousity. Spiritual comes from the word spirit which comes from the Latin word spritus which means breath. In modern terms it refers to mental energy which is non-physical including emotions and character. ${ }^{9}$

Based on the description above, it can be understood that spiritual intelligence is the ability of a human or a person to actualize his diversity in everyday life. It can be seen from one's behavior towards fellow humans and other creatures. ${ }^{10}$

Experts express opinions regarding spiritual intelligence, among others:

\section{a. Danah Zohar and Ian Marshall}

Spiritual intelligence or spiritual quotient (SQ) is the intelligence to deal with and solve life's problems regarding meaning and value, namely intelligence to place one's behavior and life in a broader and richer context of meaning, intelligence to judge that one's actions or way of life are more meaningful than with others. In this case SQ is the foundation needed to function the intelligence quotient (IQ) and emotional quotient (EQ) effectively. It is even the highest intelligence in a person. ${ }^{11}$

${ }^{8}$ Departemen Pendidikan Nasional, Kamus Besar Bahasa Insonesia Pusat Bahasa Edisi Keempat (Jakarta: PT Gramedia Pustaka Utama, 2014), 262.

9Toni Buzan, Kekuatan ESQ: 10 Langkah Meningkatkan Kecerdasan Emosional, ter. Ana Budi Kuswandi (Indonesia: PT Pustaka Delapratosa,2003), 6.

${ }^{10}$ Rusli, R. (2014c). Teaching Usul al-Fiqh: A Multicultural Education Model. Al-Tahrir: Jurnal Pemikiran Islam, 14(2), 447-464.

11Danah Zohar dan Ian Marshall, SQ: Memamfaatkan Kecerdasan Spiritual dalam Berfikir e-ISSN: 2715-4572 p-ISSN: 2716-1439 
a. Ary Ginanjar Agustian

Spiritual intelligence is the ability to give spiritual meaning to thoughts, every behavior and activity through steps and thoughts that are fitrah, towards a complete human (hanif) and have a tawhid (integralistic) mindset, and have the principle of "only because of Allah". 12

b. Toto Tasmara

Spiritual intelligence is a person's ability to listen to their conscience or the whispering of the divinely truth (referring to Allah's revelation) in the way he makes decisions or makes empathetic and adaptable choices. Spiritual intelligence is the true intelligence about wisdom and truth in divine knowledge (the creator of the universe), intelligence that produces a deep love for truth so that all actions will be guided by divine knowledge that leads to ma' rifatullah. ${ }^{13}$

d. Gay Hendrick and Kate Ludeman

Spiritual intelligence is a spirit that can provide tremendous mental energy so as to give birth to optimism, motivation or enthusiasm, discipline, integrity and honesty. ${ }^{14}$

Based on the understanding of spiritual intelligence above, it can be understood

Integralistik dan Holistik untuk Memaknai Kehidupan (Bandung: Arga, 2002), 57.

${ }^{12}$ Ary Ginanjar Agustian, Rahasia Sukses Membangun Membangun Kecerdasan Emosi dan Spiritual: ESQ(Emotional Spiritual dan Quotien) (Jakarta: Arga, 2001), 57.

13Toto Tasmara, kecerdasan Ruhaniah (Transcendental Intelegensi) (Jakarta: Gema Insani, 2001), 50 .

${ }^{14}$ Abdul Wahid Hasan, SQ Nabi: Aplikasi Strategi dan Model Kecerdasan Spiritual (SQ) Rasulullah di Masa Kini (Yogyakarta:Ircisod, 2006), 78. that spiritual intelligence is an intelligence (mental ability) that is in a person which can be seen through religious behaviors. In addition, spiritual intelligence is the highest ability possessed by a person so that it can function intellectual and emotional intelligence effectively through a sense of love and affection for others and concern for the preservation of nature because of obedience to Allah Almighty and being aware of their duties and responsibilities as a human being, namely becoming khalifah on earth.

The actualization of spiritual intelligence is the ability to solve problems correctly in a short amount of time. So it can be said that spiritual intelligence is a problem solving for someone in facing and solving problems in life. Spiritual intelligence is used to create goodness, truth, beauty, and compassion in everyday life, both for itself in families, organizations, and institutions. Spiritual intelligence is the way a person uses meaning, values, goals and motivation in the thought process of decision making.

According to Danah Zohar and Ian Marshal spiritual intelligence can foster a person's human function so as to make them creative, flexible, broad-minded, spontaneous, able to bridge between themselves and others, and become more spiritually intelligent in religion. ${ }^{15}$

The views of Danah Zohar and Ian Marshal point to significant benefits for human spiritual abilities. The benefits in question are the creation of behavioral

15Purwa Atmaja Prawira, Psikologi Pendidikan Dalam Persfektif Baru (Yogyakarta:ArRuzz Media, 2013), 137.

e-ISSN: 2715-4572 p-ISSN: 2716-1439 
changes in the cognitive, affective and psychomotor aspects which are the goals of learning. In addition, having the skills and competitiveness in a social environment, enables to deal with the dynamics of life with various problems that arise, and have quality religious attitude.

In addition, spiritual intelligence is also used to solve life problems at hand. A person is required to be creative in transforming suffering into a high life spirit (motivation) so that suffering turns into happiness. Therefore a person must be able to find the meaning of his life. So that the spiritual intelligence of students is very important to be improved and developed and optimized so that they avoid these unwanted immoral acts.

A person who has spiritual intelligence always takes care of himself and his environment in order to avoid actions that are prohibited by religion and law, this is done because of his obligation to Allah SWT. Spiritual intelligence is centered on the heart of a person which controls the movements and activities of other parts of the body which are based on the love of Allah (mahabbah ilahiyah). love is meant by the desire to give unconditionally.

The efforts made by a person to develop, improve and optimize spiritual intelligence is a form of spiritual education. Through this spiritual education a student is nurtured and trained to always carry out his obligations as a servant of Allah SWT, namely worship and do good deeds.

Solihun Masduki said that, spiritual-based education must be able to touch the innermost side of humans, namely their hearts, so that humans know and realize that they were created by Allah Almighty, born into the world with the task of worship, be grateful, love and care for fellow humans and other creatures. only because of Allah SWT, and respect for parents and teachers. ${ }^{16}$

SQ is the intelligence by which humans can direct and solve problems of meaning and value, namely intelligence in which humans place behavior and life in a broader and richer context of meaning, intelligence to judge that one's actions or way of life are more meaningful than another. ${ }^{17}$

Spiritual is one of the factors that raises the urge to increase the worship of students. Basically spiritual is to develop fitarah and / or return to nature, by empowering the reason, faith and will that Allah SWT gave him to study the guidance of Allah Almighty and His Messenger so that the fitrah that exists in that individual develops properly according to the guidance of Allah SWT ${ }^{18}$. A student who has received spiritual education in this regard with Islamic studies, his behavior and speech reflect devotion to Allah Almighty and show noble morals in every activity. This is a tangible form of spiritual intelligence possessed by a person.

Someone who has spiritual intelligence is someone who is able to

16Abuddin Nata, Pendidikan Spiritual dalam Tradisi Islam (Bandung: Angkasa, 2008), 41.

17Danah Zohar dan Ian Marshall, SQ: Spiritual Intelegence The Ultimate Intelligence terj. Rahmani Astuti, dkk, SQ: Kecerdasan Spiritual (Bandung: Mizan, Cet;IX, 2007), 3.

18Sutoyo Anwar, Bimbingan dan Konseling Islam (Yogyakarta: Pustaka Pelajar, 2014), 22.

e-ISSN: 2715-4572 p-ISSN: 2716-1439 
synergize between iman (knowledge), Islam (devotion to Allah swt) and ihsan (charity) of daily life. The term spiritual intelligence is to use a number of one's abilities precisely and perfectly to know qalbu and its activities, to manage and express it correctly, to motivate it to develop morality in relationships with other people and ubudiyah relations with Allah.

Kecerdasan spiritual merupakan kemampuan seseorang yang dapat diamati melalui aktivitas kesehariannya yang berupa sikap, siaft, dn tindakan yang diambil oleh seseorang dalam memecahkan persoalan kehidupan. Pengukuran kecerdasan spiritual dapat diketahui melalui akhlak seseorang ditinjau dari ajaran agama yang dianutnya. Pengukuran itu dilihat semakin tinggi keimanan dan ketakwaan seorang individu maka akan semakin tinggi budi pekertinya ataua akhlak akan semakin tinggi pula kecerdasan spiritualnya. Sehingga akan menjadikannya seorang individu yang memiliki kepribadian bertanggung jawab. Oleh karenanya kecerdasan spiritual dapat membentuk akhlak mulia dan memiliki kepribadian yang luhur.

Qalbu seseorang memiliki fungsi indrawi dan ruhani (spiritual), yaitu moral dan nilai-nilai etika, sehingga qalbu dapat menentukan tentang rasa bersalah, baik buru, serta mengambil keputusan berdasarkan tanggung jawab moralnya tersebut itulah sebabnya, penilaian akhir dari sebuah perbuatan dengat ditentukan oleh fungsi qalbu. Kecerdasan spiritual tidak hanya mampu mengetahui nilai-nilai, tata susila dan adat istiada saja, melainkan mampu mengetahui suara hati dari lubuk hatinya sendri yang merupakan suatu suara yang menunjukkan pada kebenaran.

Spiritual intelligence is a person's ability that can be observed through their daily activities in the form of attitudes, habits, and actions taken by someone in solving life's problems. Measuring spiritual intelligence can be known through a person's morals in terms of their religious teachings. This measurement can be seen that the higher the faith and piety of an individual, the higher the mind or character, the higher the spiritual intelligence. So that it will make him an individual who has a responsible personality. Therefore spiritual intelligence can form noble morals and have a noble personality.

Qalbu has sensory and spiritual (spiritual) functions, namely moral and ethical values, so that qalbu can determine guilt, and make decisions based on his moral responsibility that is why, the final assessment of an action is determined by qalbu. Spiritual intelligence is not only able to know values, morals and customs, but is able to know the inner voice of the heart itself which is a voice that shows the truth.

\section{Methodology}

This study uses a qualitative approach $^{19}$ with the object of research,

19 Nurdin, N., \& Yusuf, K. (2020). Knowledge management lifecycle in Islamic bank: the case of syariah banks in Indonesia. International Journal of Knowledge Management Studies, $\quad 11(1)$, 59-80. https://doi.org/10.1504/ijkms.2020.105073 
namely MAN Insan Cendekia Palu City. This school is the only Madrasah that applies education with a boarding school system in Palu City where all students are required to live in a dormitory environment.

The use of qualitative methods in this study with several considerations. First, adapting qualitative methods is easier when faced with multiple realities. Second, it can directly present the nature of the relationship between researchers and informants ${ }^{20}$. Third, this method is more sensitive and adapts itself more to the sharpening of a joint director and to the patterns of fostering student life in the dormitory. ${ }^{21}$

Data were collected using observation techniques, in-depth interviews with principals, teachers, and students. Researchers also reviewed various written documents 22. Meanwhile, data analysis was carried out using reduction and verification techniques with various data sources ${ }^{23}$. The data that has been reduced is then

${ }^{20}$ Nurdin, N. (2017a). Research in Online Space: The Use of Social Media for Research Setting Jurnal Sistem Informasi (Journal of Information System), 13(1), 67-77.

${ }^{21}$ Ibid., 5.

22 Nurdin, N. (2017b). To Research Online or Not to Research Online: Using Internet-Based Research in Islamic Studies Context. Indonesian Journal of Islam and Muslim Societies, 7(1), 31-54.

23 Nurdin, N. (2016). The Roles of Information Technology in Islamic Bank Knowledge Management: A study of Two Syariah Banks in Palu. Hunafa: Jurnal Studia Islamika, 13(2), 181-217. https://doi.org/https://doi.org/10.24239/jsi.v1 3i2.444.181-217 analyzed by confessing the theoretical concepts used in this study.

\section{Result and Discussion}

\subsection{Forms of implementation Dormitory Activities}

The dormitory activity program is carried out for students as a forum for developing religious knowledge, in order to form spiritual intelligence and improve the spiritual intelligence of students so that they can become wise and independent students. This program is expected to optimize all intelligence (multi intelligence), especially the spiritual intelligence of students so that it can be accepted in the wider community and provide positive things and can be a good role model for others.

MAN Insan Cendekia Palu City is a formal educational institution under the auspices of the Ministry of Religion, MAN Insan Cendekia Palu City is the only educational institution in Palu City that implements education with a boarding school system, so that religious activities are urgent to be carried out. This is because the activities carried out at MAN Insan Cendekia Palu City aim to increase intelligence in order to form spiritual intelligence and be able to increase knowledge, personality, noble morals, and live independently.

The form of implementation of religious activities in MAN Insan Cendekia Palu City is an effort made to form and improve spiritual intelligence, moral development and the habit of prayers by the students. This intensive coaching can help students to form and improve the spiritual intelligence that is within them. Dormitory activities are 
carried outside class hours or school hours, namely starting at 05.00 then continuing at 18.30 to 19.15 then resuming at 21:45 and ending at 22.00 and taking place every day

The formation and enhancement of spiritual intelligence, moral development and worship habits and the development of Islamic insights in this religious activity are forms of strengthening the foundations and basic potential of students' religious beliefs that have been formed from the family as informal education. This potential is enhanced and optimized through social activities in madrasah.

These activities can run optimally because with the support of the madrasah, both facilities and supervisors as well as from the parents of students. With this support students can improve their spiritual intelligence more optimal because the parents and the madrasah work together so that what parents expect and the goals of the madrasah are also realized.

Based on the author's observations, the madrasah realizes that education is not only a process of transferring information, knowledge and skills ${ }^{24}$, but with this religious activity it can be a place to form and improve spiritual intelligence, build students' morals, build awareness of prayers, become an independent students who are

24 Nurdin, N., Pettalongi, S. S., \& Mangasing, M. (2019). Understanding Digital Skill Use from The Technology Continuance Theory (TCT). 2019 6th International Conference on Information Technology, Computer and Electrical Engineering (ICITACEE) responsible, disciplined, tolerant and can increase scientific insight in the religious field. So that through education, students can become intelligent people spiritually, emotionally and intellectually.

The deputy head of the dormitory said that:

MAN Insan Cendekia Palu City implements the mission of the founder of MAN Insan Cendekia Mr. Bj. Habibie who wanted a balance between science and technology and religiousity, so that in the morning educational activities and at night, religious activities were expected to be able to grow and improve the spiritual intelligence of students. ${ }^{25}$

Based on the results of the interviews the authors conducted, the implementation of dormitory activities at MAN Insan Cendekia Palu City is how students have the ability to master science technology and religiousity, to make students who have religiousity it is necessary to form and improve spiritual intelligence. One of the religious activities is religious activity by training and familiarizing students in the process of ongoing activities so that it will train students to live independently, be disciplined, responsible and able to increase Islamic values. As for the religious activities carried out at MAN Insan Cendekia Palu City are a form of activity that is in accordance with the nationally compiled boarding school curriculum.

\footnotetext{
${ }^{25}$ Muhammad Darwis, Wakamad Keasramaan, "wawancara”, Ruang Wakamad Keasramaan, 23 Juli 2019.

e-ISSN: $2715-4572$ p-ISSN: 2716-1439
} 
Based on the author's observations, that the activities carried out at MAN Insan Cendekia Palu City are a national curriculum that has been compiled so that the MAN Insan Cendekia Palu City implements the curriculum of equality that has been established by the Central MAN Insan Cendekia. The author sees that in scheduling the implementation of this religious activity is determined by the wakamad keasramaan. So that the implementation of religious activities in MAN Insan Cendekia Palu City is well coordinated and optimally due to the implementation schedule that has been made by the district head of harmony so that the activities of togetherness run well.

The implementation of religious activities can run well with several factors that support this activity, Muhammad Darwis as the wakamad dormitory said that:

This activity went well with full support from the head of the madrasah, from supervisors with educational backgrounds relevant to religious activities and the existence of supporting facilities for the implementation of these activities, such as a prayer room, a place for students to memorize and learn (gazebo), holy books, The Alquran and other facilities. ${ }^{26}$

In addition, the appointment of a supervisor in dormitory activities is determined based on the results of the exams conducted by the madrasah, namely seeing from the educational background and the quality of the

\footnotetext{
${ }^{26}$ Muhammad Darwis, Wakamad Keasramaan, "wawancara", Ruang wakamad keasramaan, 23 Juli 2019.
}

prospective supervisor's religious insight, this is the benchmark for becoming a dormitory supervisor.

\subsection{Forms of Dormitory Activities}

1. Implementation of prayer in congregation

Dormitory activities or religious activities have a very important role in increasing the spiritual intelligence of students. In religious activities, prayer is one of the means to increase intelligence in students which is applied or implemented in MAN Insan Cendekia Palu City. This activity is a way of thinking and acting by madrasah residents who are guided by appropriate religious values. By implementing these activities, students are expected to be able to change their personality to be more Islamic and prioritize religious values in carrying out their daily activities.

Therefore it is very important to implement congregational prayers so that students are able to perform congregational prayers in increasing the spiritual intelligence of students. The implementation of congregational prayers at MAN Insan Cendekia Palu City is not an activity or program that has just been implemented. Congregational prayer activities have been carried out since the founding of this madrasah.

The congregational prayer held at MAN Insan Cendekia Palu City is an activity that must be followed by all students and this activity has been carried out since this madrasah was founded until now. 
Prayers in congregation are habituated every day. Where this prayer is carried out five times a day and is carried out every day after which other dormitory activities are carried out.

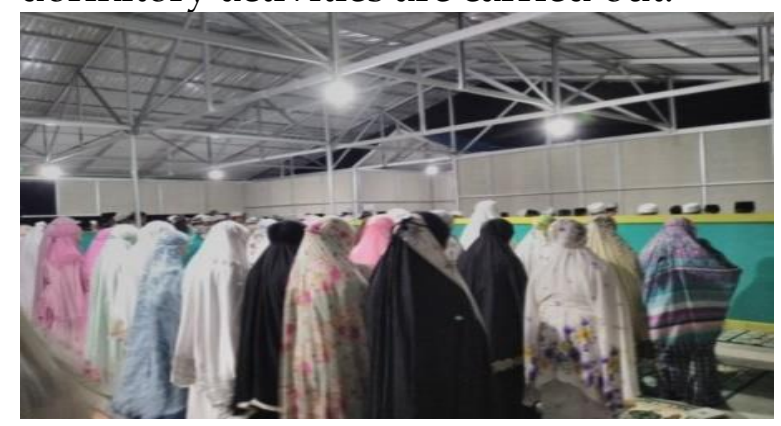

Picture 1

Students pray in congregation

2. Implementation of Qiroatul Quran

The activity of reading the Alquran at MAN Insan Cendekia Palu City is very helpful so that they can read the Alquran properly and correctly and help in memorizing the Alquran, because reading the Alquran correctly can be valuable, therefore qiroatul quran really helps students in reading the Alquran, not only that, MAN Insan Cendekia Palu City hopes that students become students who are faithful and pious, one of which is by guiding students in reading the Alquran so that they can read it well and understand it. Therefore it is important to familiarize students with reading and understanding the Alquran.

The habit of reading the Alquran which is carried out at MAN Insan Cendekia Palu City is followed by all students, so that students can read the Alquran properly and correctly.

As the statement of the dormitory supervisor, stated that:
The activity of Qiroatul Quran is a guidance given to students, namely how to provide students with understanding how to pronounce the lafadz-lafadz of the Alquran properly and correctly so as not to deviate from what is in the Alquran. This is intended so that students understand the lafadz-lafdz of the Alquran so that later students can read the Koran properly and correctly, the implementation itself is every Monday to Wednesday starting from 05.30 to 06.00 during which students are guided by the supervisor in reading the Alquran. ${ }^{27}$

Reading the Alquran is an activity that is carried out 5 times a week, starting after the Fajr prayer and ending at 6:00 a.m. The reading of the Alquran here is carried out in groups according to each class, accompanied by supervisors in each class.

The female dormitory coach stated that:

In Qiroatul quran activities, students read the Alquran sequentially according to the order of the surahs in the Alquran, and with a predetermined schedule, and are accompanied by each supervisors so that it is well coordinated. ${ }^{28}$

27Moh. Reza Lembah, Pembina Asrama Putra, "wawancara", Rumah Pembina, 27 Juli 2019.

${ }^{28}$ Dian Nirmalasari, Pembina Asrama Putri, "wawancara", Asrama Putri, 24 Juli 2019.

e-ISSN: 2715-4572 p-ISSN: 2716-1439 


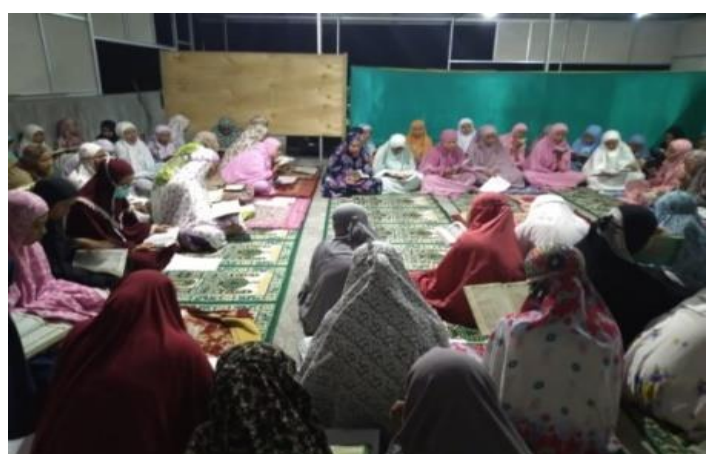

Picture 2

Dokumentasi Qiroatul quran Documentation of Qiroatull quran

Based on the above interview, the writer can understand that reading the Koran is carried out in the prayer room for men and in the dormitory for girls guided by each supervisors.

According to the results of observations made by the author, when reading the Alquran students take turns reading the Alquran and it is carried out for 30 minutes and will be corrected if there is an error in order to know how to pronounce or read the Alquran correctly.

\section{Implementation of Tahfiz Alquran}

Tahfiz Alquran which is held at MAN Insan Cendekia Palu City is an activity that must be followed by all students, where MAN Insan Cendekia Palu City requires all students to memorize the Alquran at least 5 juz as long as the students receive education at the madrasah. Therefore the role of the supervisor in this activity must be as optimal as possible so that it can be achieved what is desired, by getting used to reading the Alquran and being an imam in prayers, and of course helping students to memorize.

The habit of reading the Alquran and training students to become imam prayers at the MAN Insan Cendekia Palu City is comprehensive, this is done so that students can memorize and maintain their memorization.

Vice head of dormitory states that:

Tahfiz Alquran is a program of friendship, where the head of the madrasah hopes that students in the MAN Insan Cendekia Palu City are able to memorize 5 juz of the Alquran as long as students receive education at MAN Insan Cendekia Palu City, where students at least memorize Alquran $1 \mathrm{juz}$ in one semester, students are indeed required to memorize at least 1 juz because this is a requirement in order to graduate from MAN Insan Cendekia Palu City. 29

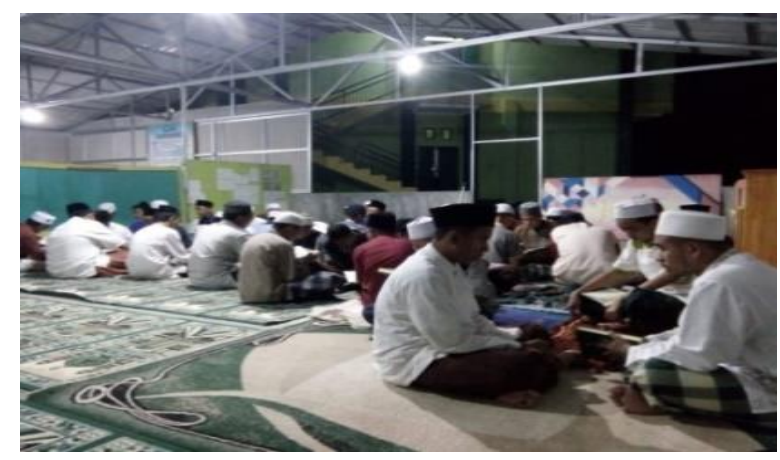

Picture 3

\section{Documentation Tahfiz Alquran}

From the author's observations, the guidance system of the Tahfiz Alquran activities is carried out by each of the supervisors and for murajaah itself it can be done at any time during the scope of the dormitory and the supervisor corrects the readings of students if

${ }^{29}$ Muhammad Darwis, Wakamad Keasramaan, "wawancara", Ruang Wakamad Keasramaan, 23 Juli 2019. 
something goes wrong and the memorization deposits is done if the students deposit evidence of previous memorization as evidence of student memorization limits.

\section{Implementation of Qiro'ah Qabla Naum}

The qiro'ah qabla naum activities here are very helpful for students in reading the Alquran. By getting used to reading the Alquran before going to bed, of course students are interested in knowing what is contained in the Alquran, the Alquran is a source of knowledge given directly by Allah to Muslims, anyone who reads and practices its contents will get a reward. MAN Insan Cendekia Palu City requires all students to read the Koran before going to bed or better known as qiro'ah qabla naum (practice before going to sleep).

The implementation of qiro'ah qabla naum which is carried out at MAN Insan Cendekia Palu City must require all students to follow it. This is done so that students get used to doing practices before going to bed, namely reading the Alquran.

The female dormitory supervisor stated that:

Reading the Alquran before going to bed or commonly known as qiro'ah qabla naum, is one of the activities routinely carried out by students every day, namely 15 minutes before bedtime, students are required to tadarrus together in their respective rooms or in the middle of the dormitory guided and controlled by supervisor. ${ }^{30}$

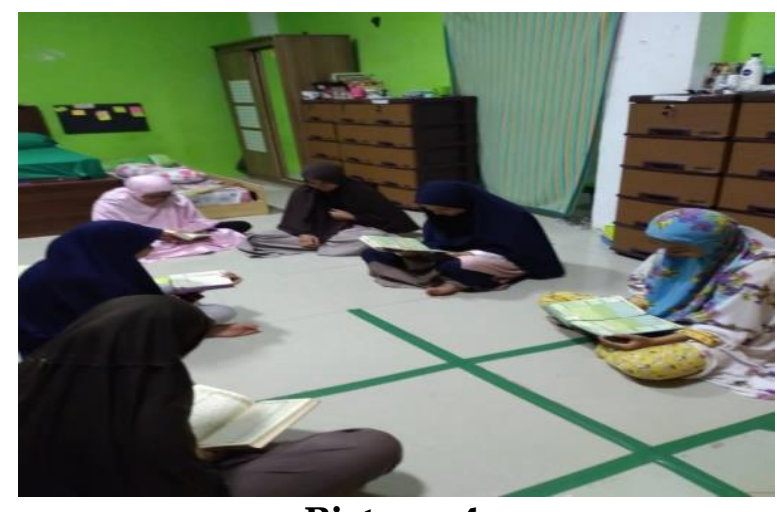

Picture 4

Documentation of qiro'ah qabla naum

The results of the interview shows that qiro'ah qabla naum is carried out in each room and it is usually done in the living room of the dormitory controlled by each supervisor with a time of about 15 minutes before going to sleep at 21.45 to 22.00 every night by reading the Almulk surah .

According to observations made by the author, at 9:45 p.m. students as a whole read surah Almulk, all students read together in each room and sometimes also in the living room of the dormitory, this activity lasts for 15 minutes, and after reading the Almulk surah students obliged to sleep and no other activities.

\section{Implementation of Qiraatul qutub /} holy book study

Qiraatul qutub activities or commonly known as holy book studies at MAN Insan Cendekia Palu City, help students to be able to study holy books

30Moh. Padil, Pembina Asrama Putra, "wawancara", Rumah Pembina, 23 Juli 2019.

e-ISSN: 2715-4572 p-ISSN: 2716-1439 
and nahwu knowledge, by knowing nahwu knowledge students will find it easier to study holy books, with holy book study activities it is hoped that students can study holy books and increase their religious knowledge.

The study of holy books carried out at MAN Insan Cendekia Palu City attended by all students, it was hoped that they would be able to study the holy book and know the contents of the holy book being studied, besides that it was also expected to be able to know the knowledge of nahwunya so that it is easier for students to study the holy book. The implementation is carried out every Friday night, and for the study of this holy book, both boys and girls are carried out in stages, for example the first week, akidatul Awwam, the second week, ta'lim al muata'alim, the third week of the hadith arbain, the fourth week of safinatunnaja '. In accordance with Moh. Padil the male dormitory supervisor said:

The material given or studied in the polar qiraatul is akidatul awwam, ta'lim muta'allim, safinatunnaja', al arba'in, these four materials are studied every week in turn. ${ }^{31}$

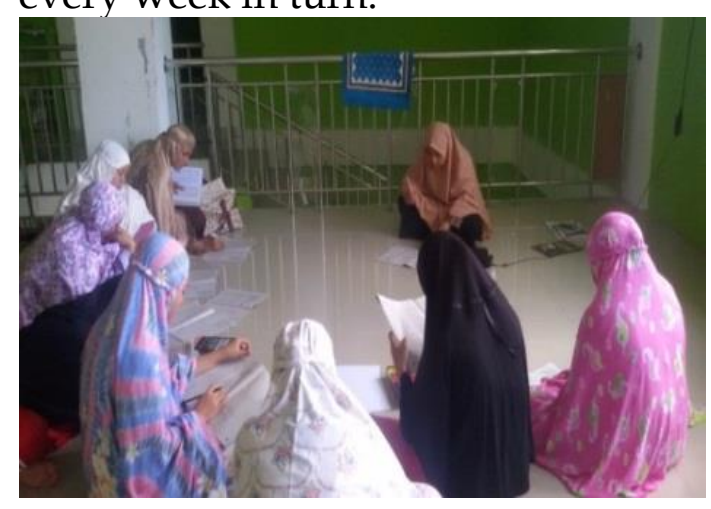

${ }^{31}$ Moh. Padil, Pembina Asrama Putra, "wawancara", Rumah Pembina 23 Juli 2019.
Picture 5

\section{Documentation of holy book study}

The results of the interview also showed that, in reviewing the holy book, the students were guided by each of the supervisors and held on Friday nights from 18.30 to 19.15 , and the holy book being studied was carried out in several stages, and for the study itself, students were given an understanding of the knowledge of nahwu first. so that later students can more easily understand the contents of the holy book being studied.

According to observations, the author sees that in the study of holy book, the supervisor provides an understanding of the knowledge of nahwu so that students can more easily understand the content of the holy book being studied, it is an effort made by the supervisor so that students make it easier for students to accept and understand the material given, as well as in its gradual implementation, for example the first week of akidatul awwam then it is then replaced with ta'lim muta'lim and so on.

Supervision in the implementation of this activity is also important so that what the coach hopes can be realized, this supervision is used to supervise students during the activity, whether students really pay attention to the material provided so that later students can understand.

\section{Conclusion}

The form of implementation of religious activities in MAN insan Cendekia Palu City is the activity of 
congregational prayer, qiroatul quran, tahfiz Alquran, Qiro'ah qabla naum, Ratibul haddal / barzanji, Qiraatul pole / book study, trilingual culture. The implementation of religious activities is carried out outside of school hours, from 05.00-05.30 and continued at 18.30-19.15 and continued again at 21.45-22.00, the activities are carried out at the mosque for male students and in the dormitory for girls, for brazanji and evening prayers and Isha all students carry out in the mushollah.

Dormitory activities have six supervisors, namely 3 male dormitory supervisor and 3 female supervisor, the dormitory supervisors are competent supervisors with activities carried out by the implementation process itself carried out by providing training, coaching and habituation so that the expected goals can be achieved.

The results of the implementation of religious activities towards increasing the spiritual intelligence of students show good results and are positive. One of them, is the increased ability of students to carry out religious activities so that they raise awareness of worship, discipline, trust, patience, tabliq, flexibility, good behavior. This dormitory activity continues to be optimized according to the vision and mission of the madrasah, namely mastering science technology based on religious values.

\section{REFERENCES}

A Miles, B Matthew. Huberman, Qualitatif Datta Analysis: A Sourcebook of New Methods.
Baverly Hills, London: Sage Publications, 1984. dikutip dalam Sugiono, Metode Penelitian Pendidika: Pendekatan Kuantitatif, Kualitatif R\&D. Cet. XIX; Bandung: Alfabeta, 2014.

A Miles, B Matthew. Qualitative Data Analisys, Terj. Tjetjep Rohendi Rohidi dengan judul Analisis DataKualitatif, buku Sumber tentang Metode-metode Baru. Cet.I; Jakarta: UI-Press, 1992.

Abdullah, Udik Meledakkan IESQ dengan Langkah Takwa dan Tawakkal Jakarta: Dzikrul Hakim, 2005.

Agustian, Ginanjar Ary. Rahasia Sukses Membangun Kecerdasan Emosi dan Spiritual ESQ Berdasarkan 6 Rukun Iman dan 5 Rukun Islam. Jakarta: Arga, 2001.

Agustian, Ginanjar Ary. Rahasia Sukses Membangun Membangun Kecerdasan Emosional dan Spiritual: EQ(Emotional Spiritual dan Quentien). Jakarta: Arga, 2005.

Ahmadi, Abu dan Nur Uhbiyati. Ilmu Pendidkan (Jakarta: Rineka Cipta, 2015.

Ainiyah, Nur. Pembetukan Karakter MelaluiPendidikan Agama Islam. Jurnal Al-Alum. Semarang, 2013.

Al Qur'an dan terjemahnya Revisi Terbaru. Departemen Agama RI. Semarang: CV. Asy-Syifa. 2000.

Anwar, Sutoyo. Bimbingan dan Konseling Islam. Yogyakarta: Pustaka Pelajar, 2014.

Arif, M. Arifuddin. Pendidikan dan Pembelajaran Agama Islam (PAI), (Palu: Endece Press, 2014.

Buzan, Toni. Kekuatan ESQ: 10 Langkah Meningkatkan 
Emosional, ter. Ana Budi Kuswandi. Indonesia: PT Pustaka Delapratosa,2003.

Catherine, Marchall and Gretchen B Rossman. Designing Qualitatif Research, $2^{\text {nd }}$ Edition (London: International Educational ond Professional Publisher, 1995), dikutip dalam Sugiono, Metode Penelitian Pendidikan : Pendekatan Kuantitatif, Kualitatif R\&D. Cet. XIX; Bandung: Alfabeta, 2014.

Departemen Pendidikan Nasional, Kamus Besar Bahasa Indonesia Pusat Bahasa Edisi Keempat. Jakarta: PT Gramedia Pustaka Utama, 2014.

Echois, M Jhon dan Hassan Sadili. Kamus Inggris Indonesia: An English Indonesiandictionary, Edisi yang diperbaharui. Cet. I; Jakarta: Gramedia Pustaka Utama, 2014.

Evita, E., Syahid, A., \& Nurdin, N. (2019). Understanding Students' Learning Outcomes Differences Through the Application of the Market Place Activity Type of Cooperative Learning Model and the Application of Conventional Learning Models International Journal of Contemporary Islamic Education, 1(1), 67-85.

Ghani, Ainal. Pendidikan Akhlak Mewujudkan Masyarakat Madani, Jurnal Al-Tadzkiyyah. 2015.

Hasan, Wahid Abdul. SQ Nabi: Aplikasi Strategi dan Model Kecerdasan Spiritual (SQ) Rasulullah di Masa Kini. Yogyakarta:Ircisod, 2006.

Kasman, Muhammad. Analisis Manajemen Kepemimpinan Kepala Madarasah dalam Mengembagkan
Mutu Sumber Daya Gurur di MAN Insan Cendekia Kota Palu, 2018.

Moleong, J Lexy. Metodologi Penelitian Kualitatif, edisi revisi. Cet. XXXV; Bandung: PT Remaja Rosdakarya, 2016.

Moleong, J. Lexy. Metodologi Penelitian Kualitatif. Bandung: Remaja Rosdakarya, 2002.

Muliawan, Ungguh Jasa. Ilmu pendidikan Islamm Studi Kasus Terhadap Struktur Ilmu, Kurikulum, Metodologi dan Kelembagaan Pendidikan Islam. Jakarta: RajaGrafindo Persada, 2015.

Muliyana. Metodologi Penelitian Kualitatif Paradigma Baru Ilmu Komunikasi dan Ilmu Sosial Lainnya. Cet. VII; Bandung: Remaja Rosdakarya, 2010.

Nasution. Metode Naturalistik Kualitatif. Bandung: Remaja RosdaKarya, 2002.

Nurdin, N., \& Yusuf, K. (2020). Knowledge management lifecycle in Islamic bank: the case of syariah banks in Indonesia. International Journal of Knowledge Management Studies, 11(1), 59-80. https://doi.org/10.1504/ijkms.20 20.105073

Nurdin, N., Pettalongi, S. S., \& Mangasing, M. (2019). Understanding Digital Skill Use from The Technology Continuance Theory (TCT). 2019 6th International Conference on Information Technology, Computer and Electrical Engineering (ICITACEE)

Nurdin, N. (2017a). Research in Online Space: The Use of Social Media for 
Research Setting Jurnal Sistem Informasi (Journal of Information System), 13(1), 67-77.

Nurdin, N. (2017b). To Research Online or Not to Research Online: Using Internet-Based Research in Islamic Studies Context. Indonesian Journal of Islam and Muslim Societies, 7(1), 31-54.

Nurdin, N. (2016). The Roles of Information Technology in Islamic Bank Knowledge Management: A study of Two Syariah Banks in Palu. Hunafa: Jurnal Studia Islamika, 13(2), 181-217. https://doi.org/https://doi.org/1 0.24239/jsi.v13i2.444.181-217

Sugiono, Metode Penelitian Pendidikan: Pendekatan Kuantitatif, Kualitatif R\&D. Cet. XIX; Bandung: Alfabeta, 2014.

Nata, Abuddin. Pendidikan Spiritual dalam Tradisi Islam. Bandung: Angkasa, 2008.

Prawira, Atmaja Purwa. Psikologi Pendidikan Dalam Persfektif Baru. Yogyakarta:Ar-Ruzz Media, 2013.

Prihatin, Eka. Manajemen Peserta Didik. Bandung: Alfabeta, 2014.

Rahmawati, Ulfa. Pengembangan Kecerdasan Spiritual Santri (Studi kasus terhadap kegiatan keagamaan di Rumah TahfizQu Deresan Putri", 2016.

Rajih, Hamdan. Mengakrabkan Anak dengan Tuhan. trj. Abdul Wahid Hasan dan Ach Maimun. Yogyakarta: Diva Press, 2002.

Rakhmat, Jalaludin. SQ for Kids. Jakarta: Mizan Pustaka, 2007.

Rusli, R. (2018). Fikih Ekologi dan Kearifan Tradisional: Tinjauan
Terhadap Konsep Ihya' al-Mawat dan Hima. Hunafa: Jurnal Studia Islamika, 5(3), 287-298.

Rusli, R. (2014c). Teaching Usul al-Fiqh: A Multicultural Education Model. Al-Tahrir: Jurnal Pemikiran Islam, 14(2), 447-464.

Rusli, R. (2020). The Role of Family in Preventing Social Conflict in Society From Islamic Perspectives. Hunafa: Jurnal Studia Islamika, 17(1), 108-122

Soekamto. Kamus Sosiologi. Jakarta: Rajawali Press, 2000.

Sudijono, Anas. Pengantar Evaluasi Pendidikan. Jakarta: Raja Gravind Persada, 2005.

Sugiono. Memahami Penelitian Kualitatif .

Cet. VII; Bandung: Alfabeta, 2015.

Sugiono. Cara Mudah menyusun Skripsi Tesis, dan Disertasi. Cet. II; Bandung: Alfabeta, 2014.

Sugiono. Memahami Penelitian Kualitatif. Cet. I; Bandung: Alfabeta, 2005.

Sukandi, Ahmad. Pengembangan kecerdasan spiritual melalui pendidikan Agama Islam (PAI), di Sekolah Menengah Kejuruan (SMK) EL-Hayat KedungKandang Kota Malang, 2016.

Sukidi. Rahasia Sukses Hidup Bahagia Kecerdasan Spiritual Mengapa SQ Lebih Penting dari pada IQ dan EQ. Jakarta: PT. Gramedia Pustaka Utama, 2002.

Sukmadinata, Syaodih Nana. Landasan Psikologi Proses Pendidikan. Bandung: PT Remaja Rosdakarya, 2016.

Sukmadinata, Syaodih Nana. Metode Penelitian Pendidikan. Cet. VI; 
Bandung: Remaja Rosdakarya, 2010.

Suryosubroto, B. Proses Belajar Mengajar di Sekolah. Jakarta: Rineka Cipta, 1992.

Susanto. Pemikiran Pendidikan Islam. Jakarta: Amzah, 2015.

Syadi, Abu Kholid. Periksalah Hati Anda.

Surakarta: Insan Kamil, 2008.

Syairozi, Mahfuz. Konsep Pendidikan

Generasi Tiga Dimensi. Jombang:

Jejak Pena, 2001.

Taqiyuddin. Pendidikan Islam dalam Lintas Sejarah Nasional. Cirebon: Pangger, 2011.

Taqiyuddin. Pendidikan Islam dalam Lintas Sejarah Nasional. Cirebon: Pangger,2011.

Tasmara, Toto. kecerdasan Ruhaniah (Transcendental Intelegensi). Jakarta: Gema Insani, 2001.

Tohirin. Metode Penelitian Kualitatif: Dalam Pendidikan dan Bimbingan Konseling. Cet. III; Jakarta: Rajagrafindo Persada, 2014.

Zohar, Danah dan Ian Marshall. SQ: Memamfaatkan Kecerdasan Spiritual dalam Berfikir Integralistik dan Holistik untuk Memaknai Kehidupan. Bandung: Arga, 2002. 